\title{
Scientific note on Apis koschevnikovi chewing petals of an orchid flower (Dipodium species O'Byrne KIP1272) in Borneo
}

\author{
Gudrun Koeniger ${ }^{1}$, Nikolaus Koeniger ${ }^{1}$, Peter O’Byrne ${ }^{2}$, Anthony Lamb ${ }^{2}$, Mananya Phiancharoen ${ }^{3}$, \\ Herbert $\mathrm{Lim}^{4}$, Samuel Tinol ${ }^{5}$, Steven Bosuang ${ }^{6}$ \\ ${ }^{1}$ Institut für Biologie, Bereich Zoologie, AG Molekulare Ökologie, Martin-Luther-Universität, Hoher Weg 4, 06120, Halle, \\ Germany \\ ${ }^{2}$ P. O. Box 10960, 88810, Kota Kinabalu, Sabah, Malaysia \\ ${ }^{3}$ King Mongkut's University of Technology, Thonburi, 209 Rang Bua, Ratchaburi, Chom Bueng 70150, Thailand \\ ${ }^{4}$ Agricultural Research Station, Lagud Seberang, 89908, Tenom, Sabah, Malaysia \\ ${ }^{5}$ Agricultural Park, Lagud Seberang, 89908, Tenom, Sabah, Malaysia \\ ${ }^{6}$ Kipandi Park, P.O. Box 12785, 88831, Kota Kinabalu, Sabah, Malaysia
}

Received 8 March 2016 - Revised 7 August 2016 - Accepted 18 August 2016

Generally, bees (Apoidea) have evolved in a close relation together with flowering plants (Michener 2007) and feed on nectar and pollen. Among the bees, Apis species are worldwide beneficial as effective pollinators, including economically important agricultural crops (Gallai et al. 2009). However, on 6 June 2014, O’Byrne observed two honey bee workers severely damaging all the open flowers of an orchid, an undescribed Dipodium species (O'Byrne KIP1272), blooming at Kipandi Park in the Crocker Range, Sabah, Malaysia. The honeybees were gnawing the sepals and petals of flowers, as well as scraping and licking the tepal surfaces and chewing the margins (Figure 1). They damaged parts of the flower that are not directly utilized for pollination, but which possibly are needed to attract the pollinator. The honeybees did not transfer anything into the corbiculae, as they do with solid material. We assume that the bees swallowed the material.

At the end of September 2014, more worker bees of the same honeybee species were observed visiting the same orchid plant. The bees, sometimes two or three at the same time, kept gnawing the flowers. Altogether,

Corresponding author: G. Koeniger, gudrun.koeniger@zoologie.uni-halle.de Manuscript Editor: Peter Rosenkranz more than ten of these foragers were observed. Five of them were preserved in ethanol and identified as Apis koschevnikovi (Koeniger et al. 2010). We detected a colony of A. koschevnikovi in a tree cavity about $100 \mathrm{~m}$ downhill from the blooming orchid. At the same time, many bees of Apis. cerana were foraging on other flowers, for example at a bottlebrush tree (Calistemon spec.) only a meter away from the orchid, but they never landed on the orchid flowers during our observations. On 9 October 2014, flowers opened on a new inflorescence of the same Dipodium orchid, but no A. koschevnikovi bees were observed and no damage was detected. When we inspected the nest cavity of A. koschevnikovi in the tree, it was occupied by an A. cerana colony.

Nothing is known about the pollinators or pollination syndromes for $D$. species, but O'Byrne (2013) suggested that these orchids use prey deception to attract predatory wasps. Several Malaysian orchids are known to be pollinated by A. cerana and A. dorsata (Ong 2010a, b), but there are no records of A. koschevnikovi pollinating orchids. We wanted to explore more about the behavior of A. koschevnikovi on orchids, and if gnawing sepals and petals is a common phenomenon or if it is a special case limited to D. spec. (O'Byrne KIP1272).

We continued our studies at the Orchid Centre within the Agricultural Research Station, Tenom, Sabah, 

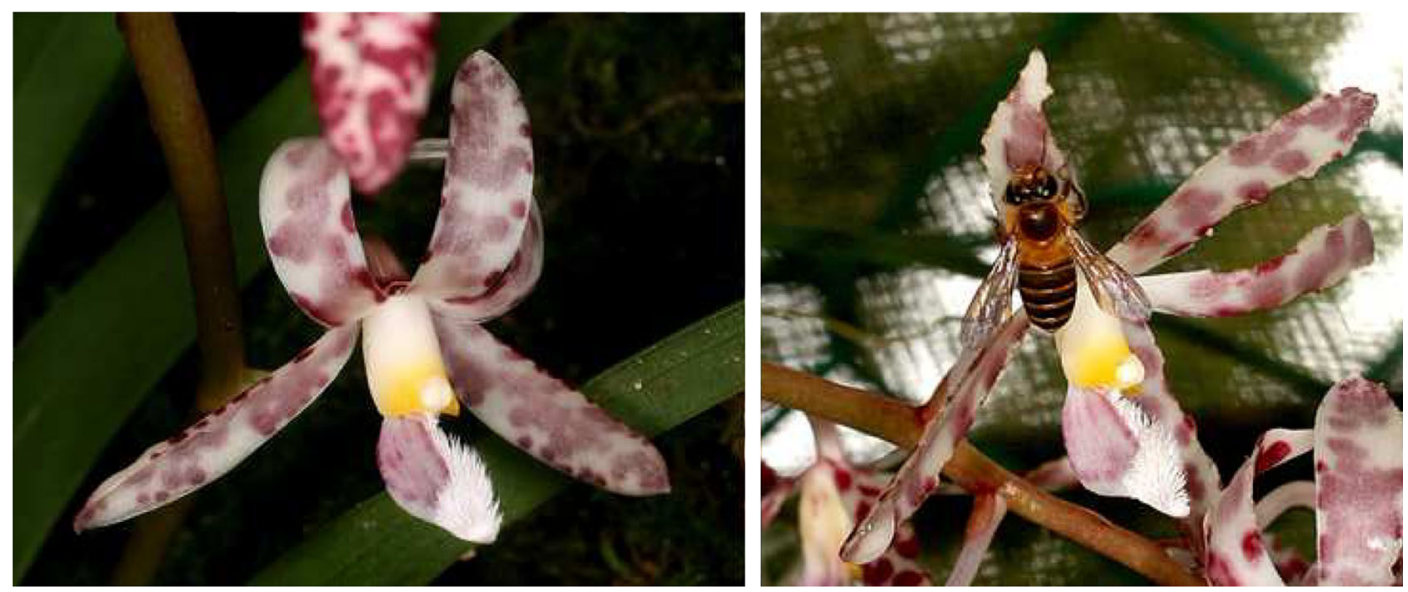

Figure 1. The photo on the left shows an intact flower of Dipodium spec. (O'Byrne KIP1272), taken on 30 May 2014. The photo on the right, taken 7 days later on 6 June 2014, shows A. koschevnikovi gnawing a flower on the same plant (photos O’Byrne).

Malaysia. In November 2014, the following 24 indigenous orchids were in bloom at the Orchid Centre: Spathoglottis plicata, Corymborkis veratrifolia, Plocoglottis acuminatum, Phaius tankervilleae, Calanthe triplicata, Trichoglottis retusa, Coelogyne rochussenii, Aerides odorata, Dendrobium anosmum, Vanda dearei, Phalaenopsis violacea, Phalaenopsi s amabilis, Phalaenopsi s cornu-cervi, Phalaenopsi s fuscata, Pseudatteri pantherina, Vanilla kinabaluensis, Bulbophyllum macranthum, Bulbophyllum singaporeanum, Paphiopedilum lowii, Paphiopedilum philippinense, Paphiopedilum rothschildianum, Paphiopedilum stonei, Renanthera bella, and Dipodium fragrans, a closely relative of D. spec. (O'Byrne KIP1272). In addition, we monitored six breeds of hybrid orchids with several hundred flowers. Two A. koschevnikovi colonies were nesting in cavities of a tree and a rock, respectively approximately 20 and $50 \mathrm{~m}$ from the Dipodium fragrans orchid. All other blooming orchids were within a radius of 50 to $150 \mathrm{~m}$ from the A. koschevnikovi nests. Further, there were a few colonies of A. cerana and several stingless bee colonies nearby.

We observed the flowers in the morning $(800 \mathrm{~h}-$ $1100 \mathrm{~h})$ for 4 days (18-21 November). At the same time, one of us checked the flight activity at the hive entrance of $A$. koschevnikovi. More than 100 bees left the hive per minute. While many forager bees of A. koschevnikovi, A. cerana, and $A$. andreniformes visited other blooming plants within the Orchid Center (Mimosa spec., several palm trees, Antigonon leptopus, Callistemon spec., Calliandra spec., etc.), no Apis forager bee was detected on the orchid flowers. During the 2 weeks of our observation, none of the orchid flowers, including $D$. fragrans, showed any sign of damage by gnawing insects. Lamb (pers. comunication) had previously observed Apis bees visiting flowers of Cymbidium atropurpureum and Cymbidium finlaysonianum, neither of which was in bloom during our study. These foragers were not chewing at the orchid flowers but appeared to be regular pollinators, departing from the flower with orchid pollinia sticking to their heads. It is not known if these two orchid species reward their pollinators, but $C$. atropurpureum flowers smell of desiccated coconut (Chan et al. 1994), presumably to attract pollinators.

In addition to the observation of orchid flowers, we studied homing A. koschevnikovi. We closed the nest entrance of a colony for $10 \mathrm{~min}$ and caught returning foragers with a net. We alternated between the two colonies. During 4 days, from $700 \mathrm{~h}-1200 \mathrm{~h}$, we captured a total of 1832 homing foragers. Each bee was examined carefully for pollen, pollinia, or other solid material and then released. No bee carried orchid pollinia, 165 bees had pollen in their corbiculae and three carried some whitish hard material in their mandibels.

This is the only report of a honeybee species chewing sepals and petals and thus destroying a flower. There is one publication on honeybees feeding on vegetative parts of plants (not on tepals) by Yokoi (2015). Worker bees of A. c. japonica feed on leaves of cultivated lettuce and, in addition, of several Asteracea plants. It is not yet clear whether 
or not A. c. japonica acquires specific compounds from these plant tissues.

The relation of $A$. koschevnikovi to the orchid D. spec. (O'Byrne KIP1272) seems to be very special, as no other honeybee species was observed to visit this orchid, though there was an A. cerana colony nearby. We hypothesize that this orchid species produces stimuli which specifically attract A. koschevnikovi foragers. Generally, bees are attracted by odors, colors and other visual stimuli of flowers, and flowers often use special characters in order to attract their pollinators (Dötterl and Verheecken, 2010). In a summary of pollination studies of 53 Chinese orchid species, Tang et al. (2014) found that of the six orchids pollinated by Apis bees, two orchid species were rewarding, three used food deception, and the other used Batesian imitation. On page 415, they discuss that "approximately half of all orchid species are thought to attract pollinators by offering a reward, while most of the remainder offer no reward, but rely on a diverse range of tricks to fool insects into pollinating their flowers".

The orchid D. spec. (O'Byrne KIP1272) is rare, currently undescribed, and seems to be restricted to Borneo (O'Byrne 2014). Both the orchid and A. koschevnikovi are indigenous in Borneo (Hadisoesilo et al. 2008; Koeniger et al. 2010). Further observations and analyses are necessary to learn more about the relation between $A$. koschevnikovi and D. spec. (O'Byrne KIP1272).

Note scientifique sur Apis koschevnikovi mâchonnant les pétales d'une orchidée (Dipodium species O'Byrne KIP1272) à Bornéo
Wissenschaftliche Notiz: Apis koschevnikovi Arbeiterinnen zernagen Blütenblätter der Orchidee Dipodium spec. (O'Byrne KIP1272) in Borneo

\section{REFERENCES}

Chan, C.L., Lamb, A., Shim, P.S., Wood, J.J. (1994) Orchids of Borneo. Vol. 1 Sabah Society \& Royal Botanic Garden, Kew

Dötterl, S., Verheecken, N.J. (2010) The chemical ecology and evolution of bee flower interactions: review and perspectives. Can. J. Zool. 88, 688-697

Gallai, N., Salles, J. M. and B. E. Vaissiere. (2009) Economic valuation of the vulnerability of world agriculture confronted with pollinator decline. Ecol. Econ 68, 810-821

Hadisoesilo, S., Raffiudin, R., Susanti, S., Atmowidi, T., Hepburn, C, Radloff, S.E., Fuchs, S., Hepburn, R. (2008) Morphometric analysis and biogeography of Apis koschevnikovi Enderlein (1906). Apidologie 39, 495-503

Koeniger, N., Koeniger, G., Tingek, S. (2010) Honey bees of Borneo: exploring the centre of Apis diversity. Natural History Publications (Borneo), Kota Kinabalu

Michener, C. D. (2007) The bees of the world. The Johns Hopkins University Press, Baltimore and London

O’Byrne, P. (2014) Two records of non-pollinating insect visits to orchid flowers. Malayan Orchid Rev. 48, 73-74

O'Byrne, P. (2013) On the evolution of Dipodium . Reinwardtia 14, 123-132

Ong P.T. (2010a). A one-day affair. Orchid Rev. 118 : 144-147

Ong P.T. (2010b). Notes on bee pollination in three peninsular Malaysian orchids. Malayan Orchid Rev. 44: 73-75

Tang G.D., Ou J.H., Luo Y.B., Zhuang X.Y., Liu Z.J. (2014). A review of orchid pollination studies in China. J. Syst. Evol. 52: 411-422

Yokoi, T. (2015) Visitation and gnawing behavior of Japanese honeybee Apis cerana japonica to lettuce. Apidologie 46, 489-494 